\title{
Bowman-Birk Inhibitors from Legumes: Utilisation in Disease Prevention and Therapy
}

\author{
Alfonso Clemente, Maria del Carmen Marín-Manzano, \\ Maria del Carmen Arques and Claire Domoney
}

Additional information is available at the end of the chapter

http://dx.doi.org/10.5772/51262

\section{Introduction}

Serine proteases have long been recognized as major players in a wide range of biological processes including cell signaling, cell cycle progression, digestion, immune responses, blood coagulation and wound healing. Their role in the physiology of many human diseases, ranging from cancer and inflammatory disorders to degenerative diseases, now represents an increasingly important feature of this family of enzymes. Proteases are tightly controlled through a number of different mechanisms, including regulation of gene expression, recognition of the substrate by the active site, activity regulation by small molecules, changes in cellular location, post-translational modifications, interaction with other proteins and/or through inhibition of proteolysis by protease inhibitors (PI) [1-3]. This last mechanism usually involves competition with substrates for access to the active site of the enzyme and the formation of tight inhibitory complexes. An understanding of the role played by serine proteases and their specific inhibitors in human diseases offers novel and challenging opportunities for preventive and/or therapeutic intervention [4].

Within this framework, there is a growing interest in naturally-occurring serine protease inhibitors of the Bowman-Birk family due to their potential chemopreventive and/or therapeutic properties which can impact on several human diseases, including cancer, neurodegenerative diseases and inflammatory disorders. In light of the Food and Drug Administration (FDA) approval for trials of Bowman-Birk inhibitors (BBI) concentrate (BBIC), a protein extract of soybean (Glycine max) enriched in BBI, as an 'Investigational New Drug', human trials have been completed in patients with benign prostatic hyperplasia [5], oral leukoplakia [6-8] and ulcerative colitis [9] (Table 1). Although, in most of these cases, the intrinsic ability of BBI to inhibit serine proteases has been related to beneficial health properties, the mechanisms of action and the identity of their therapeutic targets are 
largely unknown. In this chapter, we describe the emerging evidence for the positive contribution of BBI from legumes to disease prevention and therapy.

\begin{tabular}{|c|c|c|c|c|}
\hline Disease & Type of trial & Experimental design & Main results & Ref. \\
\hline $\begin{array}{l}\text { Benign } \\
\text { prostatic } \\
\text { hyperplasia }\end{array}$ & Phase I trial & $\begin{array}{l}\text { Duration: } 6 \text { months. } \\
19 \text { patients. Daily } \\
\text { doses up to } 800 \mathrm{CIU} \text { a }\end{array}$ & 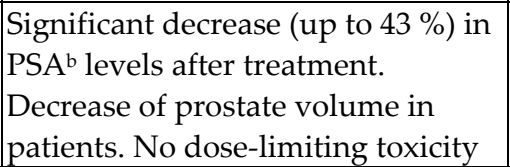 & {$[5]$} \\
\hline \multirow[t]{3}{*}{$\begin{array}{l}\text { Oral } \\
\text { leukoplakia }\end{array}$} & Phase I trial & $\begin{array}{l}\text { Duration: } 1 \text { month. } 24 \\
\text { patients. Single daily } \\
\text { dose: } 800 \text { CIU }\end{array}$ & $\begin{array}{l}\text { BBI was well tolerated. No clinical } \\
\text { evidence of toxicity or any adverse } \\
\text { reaction }\end{array}$ & [6] \\
\hline & Plase II trial & $\begin{array}{l}\text { Duration: } 1 \text { month. } 32 \\
\text { patients. } \\
\text { Administration: twice } \\
\text { daily, up to } 1066 \mathrm{CIU}\end{array}$ & $\begin{array}{l}31 \% \text { of patients achieved clinical } \\
\text { response and lesion area decreased } \\
\text { after treatment. Dose-dependent } \\
\text { effect. BBI was non-toxic. The } \\
\text { positive clinical effect of BBIC } \\
\text { could be due to the inhibition of } \\
\text { serine proteases involved in the } \\
\text { cleavage of neu-oncogen protein on } \\
\text { the cell surface, preventing the } \\
\text { release of the extracellular domain } \\
\text { of the protein into the bloodstream }\end{array}$ & {$[7]$} \\
\hline & $\begin{array}{l}\text { Double-blind } \\
\text { randomized, } \\
\text { Placebo- } \\
\text { controlled } \\
\text { phase IIb } \\
\text { trial } \\
\end{array}$ & $\begin{array}{l}148 \text { patients. Daily } \\
\text { dose: } 600 \text { CIU }\end{array}$ & $\begin{array}{l}\text { Although this study has not been } \\
\text { completed yet, preliminary results } \\
\text { suggest that BBIC is not fully } \\
\text { effective in patients }\end{array}$ & {$[8]$} \\
\hline $\begin{array}{l}\text { Ulcerative } \\
\text { colitis }\end{array}$ & \begin{tabular}{|l|} 
A \\
randomized, \\
double \\
blind, \\
placebo- \\
controlled \\
trial \\
\end{tabular} & $\begin{array}{l}12 \text { weeks of therapy. } \\
28 \text { patients. Daily } \\
\text { dose: } 800 \text { CIU }\end{array}$ & $\begin{array}{l}\text { BBIC might be associated with the } \\
\text { regression of disease without } \\
\text { apparent toxicity or adverse side } \\
\text { effects }\end{array}$ & [9] \\
\hline
\end{tabular}

aCIU: chymotrypsin inhibitory units; bPSA: prostate specific antigen

Table 1. Clinical trials utilizing a protein extract of soybean enriched in Bowman-Birk inhibitors (BBIC)

\section{The Bowman-Birk family}

\subsection{Sources and occurrence}

Plant PI can be categorized into at least 12 different families with 10 of these targeting serine proteases and adopting the standard mechanism of inhibition [10]. Members of the 
Bowman-Birk family are canonical serine PI of low molecular weight, being particularly abundant in legume seeds. Soybean BBI represent the most extensively studied members of the Bowman-Birk family, but related BBI from other dicotyledonous legumes [including chickpea (Cicer arietinum), common bean (Phaseolus vulgaris), lentil (Lens culinaris) and pea (Pisum sativum)] and from monocotyledonous grasses (Poaceae) [including wheat (Triticum aestivum), rice (Oryza sativa) and barley (Hordeum vulgare) species], have been identified and characterized.

The BBI that are expressed in seeds are the products of multi-gene families. Several isoinhibitors have been identified in seeds of individual species [11, 12]. The expression of distinct genes, together with the post-translational modifications of primary gene products, combine to give rise to the array of BBI-like variants described for many legume species. Variants in overall and active site sequences, size, functional properties and spatial pattern of expression have been described [13]. As a result, qualitative and quantitative differences in protease inhibitory activities have been shown in comparisons of pea genotypes [14, 15]. The close linkage of the genes encoding BBI, demonstrated for a number of legume species [16], allows the development of near-isolines having distinct haplotypes. In pea, the cosegregation of quantitative and qualitative variation has been used to develop a series of near-isolines, which have allowed the biological significance of a five-fold variation in seed protease inhibitory activity to be investigated at the level of ileal digestibility $[17,18]$. These lines now facilitate related studies on the positive contribution of seed BBI to the prevention of disease states.

The occurrence of BBI in soy foods (soymilk, soy infant formula, defatted soy meal, oilcake, tofu, soybean protein isolate and soybean protein concentrate, among others) is noteworthy, where BBI may be present in different amounts. The soy varieties used, the products themselves and the technological processes used in their preparations all contribute to variation in BBI concentration. In order to quantify BBI in soy foods, enzymatic and immunological methods have been developed; however, no comprehensive information on the concentration of BBI in soy foods is available currently. Recently, Hernández-Ledesma et al. [19] reported BBI concentrations in 12 soymilk samples ranging from 7.2 to $55.9 \mathrm{mg} \mathrm{BBI} / 100 \mathrm{~mL}$ of soymilk, while BBI was not detected in a soy-based infant formula. BBI was also reported in tofu samples, with concentrations ranging between 2.9 and $12.4 \mathrm{mg} / 100 \mathrm{~g}$ product. Since BBI could not be detected in natto and miso samples, it may be assumed that BBI were degraded during the fermentation process.

\subsection{Inhibitory properties}

The inhibitory activity of BBI is due to the formation of stable complexes between the inhibitor and target proteases. The conformation of the reactive site loop is complementary to the active site of the protease inhibited and allows BBI to bind tightly to proteases in a substrate-like manner [20, 21]; the resulting non-covalent complex renders the target 
protease inactive. Upon complex formation, BBI may be cleaved very slowly (low $\left.K_{\text {cat }}\right)$. In legumes, the enzyme inhibitory activity is associated with two subdomains of the BBI, located at opposite sides of the molecule; each canonical loop is contained within a nonapeptide region joined via a disulphide bond between flanking cysteine residues. The double-headed BBI have a characteristic highly conserved array of intra-molecular disulphide bridges occurring among 14 Cys residues [22]. The two binding loops can each inhibit independently and simultaneously an enzyme molecule, which may be the same or distinct types of enzyme [13]. The specificity of each reactive site is determined by the identity of the amino acid residue in position $\mathrm{P}_{1}$ [23]. In double-headed BBI, the first active site is usually involved in trypsin inhibition, with the $\mathrm{P}_{1}$ position being occupied by Arg or Lys. The presence of an Ala residue at the $\mathrm{P}_{1}$ position has been reported to be associated with inhibition of elastase [24]. Chymotrypsin is often the target of the second inhibitory domain as it has a hydrophobic amino acid in its $\mathrm{P}_{1}$ position [13, 25]. Additional residues adjacent to the reactive site peptide bond $\left(\mathrm{P}_{1}-\mathrm{P}_{1}{ }^{\prime}\right)$ can have a significant effect on the affinity of BBI for particular protease targets [13]. BBI from legumes include potent inhibitors of both trypsin and chymotrypsin, with $K_{\mathrm{i}}$ values within the nanomolar range reported for different members, including soybean [26], pea [27, 28], lentil [29, 30] and lupin (Lupinus albus) BBI [31].

\section{Bioavailability and metabolism of BBI}

In order to exert any local or systemic health benefits, dietary BBI must resist degradation and maintain biological activity, at least to some extent, after food processing and further passage through the gastrointestinal tract (GIT) [22]. BBI from several legume sources have been shown to resist thermal treatment (up to $100{ }^{\circ} \mathrm{C}$ ), under either neutral or acidic conditions [32]. Most of the heat-resistant trypsin inhibitory activity in processed legumes is attributable to BBI. At temperatures of $80^{\circ} \mathrm{C}$ or lower, chickpea BBI were found to be stable and their inhibitory activities to be unaffected by thermal treatment [33]. Soybean BBI do not lose activity at $\mathrm{pH}$ values as low as 1.5 in the presence of pepsin at $37^{\circ} \mathrm{C}$ for $2 \mathrm{~h}$ [34]; these proteins are also stable to both the acidic conditions and the action of digestive enzymes under simulated gastric and intestinal digestion [35]. Such stability is associated with the rigid structure provided by the seven intra-molecular disulphide bridges that maintain the structural and functional features of the binding sites by adding covalent attachment to the inhibitor core [10,36]. BBI are fully inactivated by autoclaving or reduction of their disulphide bridges followed by alkylation of the cysteinyl sulfhydryl groups [26].

The resistance of BBI to extreme conditions within the GIT may favour the transport of biologically active BBI across the gut epithelium and could allow their distribution to target organs or tissues in order to exert their beneficial effects locally. The uptake and distribution of soybean BBI, following oral administration, has been examined in rodents. By using $\left.{ }^{[125} \mathrm{I}\right] \mathrm{BBI}$, it was demonstrated that BBI becomes widely distributed in 
mice $3 \mathrm{~h}$ after oral administration [37]. Labelled BBI was detected in the luminal contents of the small and large intestine; analysis of tissue homogenates revealed also the presence of active BBI in internal organs where soybean BBI have been shown to exert anti-carcinogenic effects (see next section). By using inverted sacs from different sections of the small intestine, it was demonstrated that active BBI could be transported effectively across the gut epithelium. It has been shown that soybean BBI have a serum half-life of $10 \mathrm{~h}$ in rats and hamsters, and are excreted in urine and faeces [38]. In humans, BBI are taken up rapidly and can be detected in the urine within 24-48 $\mathrm{h}$ [6]. These findings suggest that BBI are absorbed after oral administration and can reach several tissues and organs.

BBI have potential health-promoting properties within the GIT [22]. In vivo studies have demonstrated the presence of active BBI in the small intestine. Hajós et al. [39] reported the survival ( $5 \%$ of total ingested) of soybean BBI in an immunological reactive form in the small intestine of rats; unfortunately, the inhibitory activities of BBI were not evaluated in these experiments. More recently, it has been demonstrated that BBI from chickpea seeds can resist both acidic conditions and the action of digestive enzymes, and transit through the stomach and small intestine of pigs, generally held as a suitable model for human digestive physiology [40]. The presence of active BBI (5-8 \% of the total ingested BBI) at the terminal ileum revealed the resistance of at least some, or a significant proportion, of these proteins to the extreme conditions of the GIT in vivo. Chromatographic, electrophoretic and enzymatic data obtained from ileal samples suggested that most of the BBI activity is derived from a protein core containing the two binding domains, and resistant to proteolysis. In vitro incubation studies of soybean BBI with mixed fecal samples of pigs showed that BBI remained active and their intrinsic ability to inhibit serine proteases was not significantly affected by the enzymatic or metabolic activity of fecal microbiota [41]. All of these results are significant to investigations of the potential uses of BBI in preventive or therapeutic medicine.

\section{Chemopreventive properties of Bowman-Birk inhibitors}

Chemoprevention is the use of natural agents or synthetic drugs to halt or reverse the carcinogenesis process before the emergence of invasive cancer. The fact that certain dietary constituents can exert chemopreventive properties has major public health implications and the widespread, long-term use of such compounds should be promoted in populations at normal risk, based on understanding the scientific basis of their beneficial effects. In particular, BBI have been linked to a possible protective effect against both inflammatory disorders and cancer development (Table 2).

\subsection{Colorectal cancer}

Nutritional intervention and/or dietary manipulation have been suggested as key strategies to prevent and/or control colorectal carcinogenesis [42, 43], one of the major causes of 
cancer-related mortality worldwide in both men and women [44]. There is now robust preclinical evidence to suggest that dietary BBI from several legume sources can prevent or suppress cancer development and associated inflammatory disorders within the GIT [22]. Soybean BBI have been reported to be effective at concentrations as low as $10 \mathrm{mg} / 100 \mathrm{~g}$ diet, in reducing the incidence and frequency of colorectal tumors, in studies based on the dimethylhydrazine (DMH) rat model, where no adverse effect of BBI was documented for animal growth or organ physiology [45]. When the inhibitory activity of BBI is abolished, any suppressive effect on colorectal tumor development disappears, suggesting that the inhibitory properties of BBI against serine proteases may be required for their reported chemopreventive properties. Proteases play a critical role in tumorigenesis, where their activities become dysregulated in colorectal cancer and neoplastic polyps [46]. In particular, serine proteases are key players in several biological functions linked to tumor development, including cell growth (dys)regulation and cell invasion as well as angiogenesis and inflammatory disorders. Some of these proteases have been reported as promising cancer biomarkers [47-49] (Table 3). An understanding of the role played by specific serine proteases in the biological processes associated with disease may suggest modes of therapeutic intervention $[1,50]$. Successful examples of therapeutic intervention using PI include ubiquitin-proteasome inhibitors in the treatment of multiple myeloma [51]. The ubiquitin-proteasome pathway is essential for most cellular processes, including protein quality control, cell cycle, transcription, signalling pathways, protein transport, DNA repair and stress responses [52]. Inhibition of proteasome activity leads to accumulation of poly-ubiquitinylated and misfolded proteins, endoplastic reticulum stress and eventually apoptosis. Although soybean BBI has been demonstrated to inhibit the proteasomal activity of MCF7 breast cancer cells (see section 4.4), the proteasomal inhibition in colon cancer cells need to be unambiguously demonstrated. Another potential therapeutic target of BBI is matriptase (also known as MT-SP1 or epithin), an epithelial-specific member of the type II transmembrane serine protease family, which plays a critical role in differentiation and function of the epidermis, gastrointestinal epithelium and other epithelial tissues. Several studies suggest that matriptase is overexpressed in a wide variety of malignant tumors including prostate, ovarian, uterine, colon, epithelial-type mesothelioma and cervical cell carcinoma [53]. It has been proposed to have multiple functions, acting as a potential activator of critical molecules associated with tumor invasion and metastasis. MT-SP1 contributes to the upstream activation of tumor growth and its progression through the selective degradation of extracellular matrix proteins and activation of cellular regulatory proteins, such as urokinase-type plasminogen activator, hepatocyte-growth factor/scatter factor and protease-activated receptor [54]. Although the ability of soybean BBI to inhibit a secreted form of recombinant MT-SP1 has been demonstrated [55], the clinical relevance of such inhibition has not been proven yet. The validation of specific serine proteases as BBI targets, together with the identification of natural BBI variants, and the design of specific potent inhibitors of these proteases, will contribute to the assessment of BBI as colorectal chemopreventive agents for preventive and/or therapeutic medicine [22]. 


\begin{tabular}{|c|c|c|c|c|c|}
\hline $\begin{array}{l}\text { Cancer } \\
\text { type }\end{array}$ & BBI source & Carcinogen & Model system & $\begin{array}{c}\text { Effect and/or mechanisms of } \\
\text { action }\end{array}$ & Refs. \\
\hline \multirow[t]{8}{*}{ Colorectal } & Soybean & $\mathrm{DMH}^{\mathrm{a}}$ & $\begin{array}{l}\text { Colon } \\
\text { carcinogenesis } \\
\text { in rodents }\end{array}$ & $\begin{array}{l}\text { Reduction of incidence and } \\
\text { frequency of tumors likely via } \\
\text { protease inhibition }\end{array}$ & {$[45]$} \\
\hline & Soybean & $\mathrm{DMH}$ & $\begin{array}{l}\text { Mouse colon } \\
\text { and anal } \\
\text { inflammation }\end{array}$ & $\begin{array}{l}\text { Suppression of adenomatous } \\
\text { tumors of the GIT }\end{array}$ & [56] \\
\hline & Soybean & DSS $^{b}$ & $\begin{array}{l}\text { Mouse colon } \\
\text { inflammation }\end{array}$ & $\begin{array}{l}\text { Suppression of histological } \\
\text { inflammation parameters, } \\
\text { lower mortality rate and } \\
\text { delayed onset of mortality }\end{array}$ & {$[57]$} \\
\hline & Horsegram & $\mathrm{DMH}$ & $\begin{array}{l}\text { Colorectal } \\
\text { carcinogenesis }\end{array}$ & $\begin{array}{l}\text { Protective role against } \\
\text { inflammation and pre- } \\
\text { neoplastic lesions }\end{array}$ & {$[58]$} \\
\hline & Lentil & - & $\begin{array}{l}\text { Colon cancer } \\
\text { cells }\end{array}$ & $\begin{array}{l}\text { Proliferation of HT29 colon } \\
\text { cancer cells was decreased } \\
(\mathrm{IC} 50=32 \mu \mathrm{M}) \text {, whereas the } \\
\text { non- malignant fibroblastic } \\
\text { CCD18Co cells were } \\
\text { unaffected }\end{array}$ & {$[30]$} \\
\hline & Pea & - & $\begin{array}{l}\text { Colon cancer } \\
\text { cells }\end{array}$ & $\begin{array}{l}\text { The anti-proliferative effect of } \\
\text { BBI in colon cancer cells are } \\
\text { demonstrated }\end{array}$ & [15] \\
\hline & Soybean & - & $\begin{array}{l}\text { Colon cancer } \\
\text { cells }\end{array}$ & $\begin{array}{l}\text { Time- and concentration- } \\
\text { dependent anti-proliferative } \\
\text { effect on HT29 cells, arrest at } \\
\text { G0-G1 phase; trypsin- and } \\
\text { chymotrypsin-like proteases } \\
\text { are potential targets }\end{array}$ & [26] \\
\hline & $\begin{array}{l}\text { Recombi- } \\
\text { nant } \\
\text { proteins }\end{array}$ & - & $\begin{array}{l}\text { Colon cancer } \\
\text { cells }\end{array}$ & $\begin{array}{l}\text { rTI1B, a major BBI isoinhibitor } \\
\text { from pea, having trypsin and } \\
\text { chymotrypsin inhibitory } \\
\text { activity, affected the } \\
\text { proliferation of colon cancer } \\
\text { cells; however, a derived } \\
\text { inactive mutant did not } \\
\text { show any anti-proliferative } \\
\text { effect }\end{array}$ & {$[68]$} \\
\hline Gastric & Field bean & $\begin{array}{l}\text { Benzo- } \\
\text { pyrene }\end{array}$ & $\begin{array}{l}\text { Mouse stomach } \\
\text { carcinogenesis }\end{array}$ & $\begin{array}{l}\text { BBI was more effective in } \\
\text { prevention than in therapeutic } \\
\text { treatment, with activity } \\
\text { related to its protease } \\
\text { inhibitory ability }\end{array}$ & {$[100]$} \\
\hline
\end{tabular}




\begin{tabular}{|c|c|c|c|c|c|}
\hline $\begin{array}{c}\text { Cancer } \\
\text { type }\end{array}$ & BBI source & Carcinogen & Model system & $\begin{array}{l}\text { Effect and/or mechanisms of } \\
\text { action }\end{array}$ & Refs. \\
\hline \multirow[t]{2}{*}{ Breast } & $\begin{array}{l}\text { Black-eyed } \\
\text { pea }\end{array}$ & - & $\begin{array}{l}\text { Breast cancer } \\
\text { cells }\end{array}$ & $\begin{array}{l}\text { BBI induced apoptosis, cell } \\
\text { death and lysosome } \\
\text { membrane permeabilization }\end{array}$ & {$[79]$} \\
\hline & Soybean & - & $\begin{array}{l}\text { Breast cancer } \\
\text { cells }\end{array}$ & $\begin{array}{l}\text { Proteasome was reported as } \\
\text { potential therapeutic target in } \\
\text { MCF-7 cells }\end{array}$ & {$[78]$} \\
\hline \multirow[t]{3}{*}{ Prostate } & Soybean & - & $\begin{array}{l}\text { Prostate cancer } \\
\text { cells and rat } \\
\text { prostate } \\
\text { carcinogenesis }\end{array}$ & $\begin{array}{l}\text { BBI exerted chemopreventive } \\
\text { activity associated with } \\
\text { induction of connexin- } 43 \\
\text { expression and apoptosis }\end{array}$ & {$[76,77]$} \\
\hline & Soybean & - & $\begin{array}{l}\text { Prostate cancer } \\
\text { xeno-grafts in } \\
\text { nude mice }\end{array}$ & $\begin{array}{l}\text { BBI and BBIC inhibited the } \\
\text { growth of LNCaP cells }\end{array}$ & {$[72]$} \\
\hline & Soybean & - & $\begin{array}{l}\text { Prostate cancer } \\
\text { cells }\end{array}$ & $\begin{array}{l}\text { BBI prevented the generation } \\
\text { of activated oxygen species } \\
\text { and activated DNA repair } \\
\text { through a p53-dependent } \\
\text { mechanism }\end{array}$ & {$[74,75]$} \\
\hline Oral & Soybean & - & $\begin{array}{l}\text { Oral } \\
\text { leukoplakia }\end{array}$ & $\begin{array}{l}\text { BBIC exerted a dose- } \\
\text { dependent reduction in oral } \\
\text { lesion size in } 31 \% \text { of patients } \\
\text { without any adverse effects; } \\
\text { modulation of protease } \\
\text { activity and neu oncogene } \\
\text { levels was observed }\end{array}$ & {$[6,7,69]$} \\
\hline
\end{tabular}

aDMH: dimethylhydrazine; bDSS: dextran sulphate sodium

Table 2. In vitro and in vivo studies showing chemopreventive properties of Bowman-Birk inhibitors

A strong interest exists in investigating the potential of BBI as anti-inflammatory agents within the GIT. In rodents, soybean BBI treatment appears to have a potent suppressive effect on colon and anal gland inflammation, following exposure to carcinogenic agents [56], or when assessed in an acute injury/colitis model [57]. The protective effect of BBI from soybean or those from perennial horsegram (Macrotymola axillare) against inflammation and development of pre-neoplastic lesions induced in the DMH mouse model was reported recently [58]. Given the lack of toxicity as well as the reported anti-inflammatory properties in animals, the potential for BBIC to benefit patients with ulcerative colitis has been evaluated. In a randomized double-blind placebo-controlled trial, a dose of 800 chymotrypsin inhibitor units (CIU) per day over a three-month treatment period was associated with a clinical response and induction of remission, as assessed by the Sutherland Disease Activity Index score [59], in patients with ulcerative colitis, without apparent toxicity [9]. Approximately $50 \%$ of patients responded clinically and $36 \%$ showed 
remission of disease. Several mechanisms have been proposed to explain the antiinflammatory properties of BBI. The ability of BBI to decrease the production and release of superoxide anion radicals, mediators of inflammatory processes, in purified human polymorphonuclear leukocytes [60] and in differentiated HL60 cells [59] has been reported. The decrease in superoxide radical levels may reduce free radical-induced DNA damage and transformation to malignant phenotypes. In addition, superoxide radicals can initiate a wide range of toxic oxidative reactions, including lipid peroxidation. In this regard, it has been demonstrated that BBI can reduce the content of lipid peroxides in irradiated cells in vitro [61], a reduction that is presumed to be linked to the anti-inflammatory activity of BBI. The role that certain serine proteases play during proteolysis in acute and chronic inflammatory processes is well recognized. The ability of soybean BBI to inhibit serine proteases involved in inflammatory processes, such as cathepsin G [62, 63], elastase [64] and mast cell chymase [64] has been reported. The last enzyme acts as a chemo-attractant and may play a role in the accumulation of inflammatory cells during development of allergic and non-allergic diseases [65]. The interaction of chymase and BBI may impact on other processes involved in anti-inflammatory responses, such as the regulation of collagenase [66] and interleukin $1 \beta$ (IL-1 $\beta$ ) [67]. Nevertheless, a clear correlation between the inhibition of these serine proteases and the anti-inflammatory properties associated with soybean BBI has not been demonstrated clearly [22].

\begin{tabular}{|c|c|c|c|}
\hline $\begin{array}{c}\text { Serine } \\
\text { protease }\end{array}$ & Function & Pathological process & Refs. \\
\hline Tryptase & $\begin{array}{l}\text { Phagocytosis, degradation of } \\
\text { ECM }^{\text {a }} \text { compounds, regulation of } \\
\text { inflammatory responses, blood } \\
\text { coagulation }\end{array}$ & $\begin{array}{l}\text { Atherosclerosis, asthma, } \\
\text { inflammatory disorders }\end{array}$ & $\begin{array}{l}{[97,} \\
98]\end{array}$ \\
\hline Cathepsin G & $\begin{array}{l}\text { ECM degradation, migration, } \\
\text { regulation of inflammatory } \\
\text { disorders }\end{array}$ & Inflammation, metastasis & [62] \\
\hline Matriptase & $\begin{array}{l}\text { Matrix degradation, regulation } \\
\text { of intestinal barrier, iron } \\
\text { metabolism }\end{array}$ & $\begin{array}{l}\text { Pathogenesis of epithelial } \\
\text { tissues, tumor growth and } \\
\text { progression }\end{array}$ & [55] \\
\hline $\begin{array}{l}\text { Human } \\
\text { elastase }\end{array}$ & $\begin{array}{l}\text { Pathogen killing, ECM } \\
\text { degradation, inflammatory } \\
\text { disorders }\end{array}$ & $\begin{array}{l}\text { Pulmonary disease, } \\
\text { inflammation }\end{array}$ & $\begin{array}{l}{[62,} \\
99]\end{array}$ \\
\hline Chymase & $\begin{array}{l}\text { Degradation of ECM } \\
\text { compounds, regulation of } \\
\text { inflammatory responses }\end{array}$ & $\begin{array}{l}\text { Inflammation, asthma, } \\
\text { gastric cancer }\end{array}$ & [64] \\
\hline Proteasome & $\begin{array}{l}\text { Protein degradation, cell } \\
\text { proliferation, differentiation, } \\
\text { angiogenesis and apoptosis }\end{array}$ & $\begin{array}{l}\text { Carcinogenesis, } \\
\text { inflammation, neurodeg- } \\
\text { eneration }\end{array}$ & $\begin{array}{l}{[58,} \\
78]\end{array}$ \\
\hline
\end{tabular}

aECM: extracellular matrix

Table 3. Serine proteases involved in pathological processes as potential therapeutic targets of soybean BBI and related proteins (adapted from Clemente et al., 2011 [22]). 
In previous studies, a significant concentration- and time-dependent decrease in the growth of an array of colon cancer cells (HT29, Caco2, LoVo) has been demonstrated in vitro, following treatment with BBI variants from several legume sources, including pea, lentil and soybean; in contrast, the growth of non-malignant colonic fibroblastic CCD18-Co cells was unaffected by BBI $[15,26,30]$. Recently, the anti-proliferative effect of rTI1B, a major pea isoinhibitor expressed heterologously in Pichia pastoris, has been evaluated using colon cancer cells grown in vitro. Comparisons of the effects of rTI1B with those observed using a related synthetic mutant derivative, showed that the proliferation of HT29 colon cancer cells was inhibited significantly by rTI1B in a dose-dependent manner, whereas the mutant which lacked trypsin and chymotrypsin inhibitory activity did not show any significant effect on colon cancer cell growth (Figure 1) [68]. Although the molecular mechanism(s) of this chemopreventive activity remains unknown, the reported data indicate that both trypsin- and chymotrypsin-like serine proteases involved in carcinogenesis are likely primary targets for BBI.

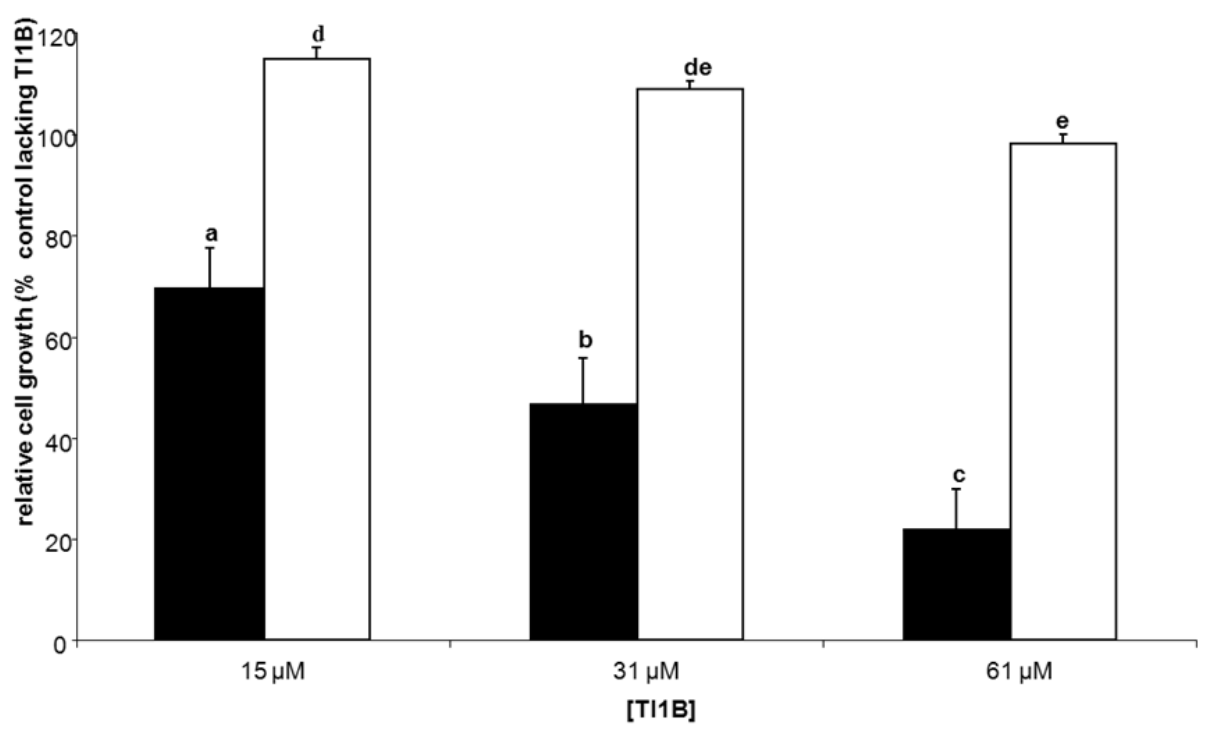

Figure 1. Dose-response effects of rTI1B (closed bars), a major pea isoinhibitor expressed in Pichia pastoris, and the corresponding inactive mutant (open bars), having amino acid substitutions at the $\mathrm{P}_{1}$ positions in the two inhibitory domains, on the in vitro growth of HT29 human colorectal adenocarcinoma cells. Growth media were supplemented with rTI1B in the concentration range 15-61 $\mu \mathrm{M}$ and cells harvested after a period of $96 \mathrm{~h}$. Data are means of at least three independent experiments, each having four technical replicates; bars represent standard deviations. Means not sharing superscript letters differ significantly ( $p<0.05$; Bonferroni's test) (Adapted from Clemente et al., (2012) [68]).

\subsection{Oral leukoplakia}

Leukoplakia in the oral cavity is considered a suitable model for the study of chemoprevention because the precancerous lesions are readily accessible to visual 
examination, diagnostic sampling and evaluation of response to treatment. In a Phase I clinical trial, no clinical evidence of toxicity or any adverse effect was apparent when BBIC was administered as a single oral dose of up to $800 \mathrm{CIU}$ to twenty-four patients with oral leukoplakia over one month-period [6]. The study revealed that BBIC was well-tolerated and no allergic reactions, gastrointestinal side-effects or other clinical symptoms were elicited. In a non-randomized phase IIa clinical trial, treatment with BBIC for one month resulted in a dose-dependent reduction in oral lesion size in $31 \%$ of patients [7]. The positive clinical effect of BBIC was associated with modulation of protease activity and neu oncogene levels (as the surrogate endpoint biomarker for the trial) in exfoliated oral mucosal cells [7, 69]; however, this evidence is indirect and the specific target proteases inhibited were not reported. A recent phase IIb randomized, double-blind, placebo-controlled trial involving patient treatment with BBIC for six months was performed. Even though this multiinstitutional study has not been completed yet, BBIC does not seem to be fully effective as chemopreventive agent for the management of oral leukoplakia [8].

\subsection{Prostate cancer}

Prostate cancer is the second most frequently diagnosed cancer in men although the incidence of cancer varies greatly throughout the world. Dietary habits and lifestyle have been identified as major risk factors in prostate cancer growth and progression, suggesting that prostate cancer might be preventable [70]. Epidemiological studies have shown an inverse association between soy intake and the risk of developing prostate cancer [71]. Preclinical and clinical studies have shown the potential chemopreventive properties of BBI in prostate cancer. Purified soybean BBI and BBIC have been shown to inhibit the growth of LNCaP human prostate cancer xenografts in nude mice [72], and to decrease the growth, invasion and clonogenic survival of several human prostate cancer cells [73]. The effectiveness of soybean BBI in preventing the generation of activated oxygen species in prostate cancer cells [74] and in activating DNA repair through a p53-dependent mechanism has been reported [75]. More recently, BBIC has prevented the growth of prostate tumors in transgenic rats developing adenocarcinoma, most likely as a consequence of its antiproliferative activity via induction of connexin 43 expression [76, 77]. In humans, a doubleblind, randomized, phase I trial was carried out in nineteen male subjects with benign prostatic hyperplasia, which is a precursor condition for prostate cancer, and lower urinary tract symptoms [5]. In this study, the authors demonstrated that BBIC treatment for six months reduced levels of prostate-specific antigen (PSA), a clinical marker for prostate cancer, and prostate volume in patients. Additional clinical studies will be necessary to determine the potential of BBIC as prostate cancer chemopreventive agent.

\subsection{Breast cancer}

Breast cancer is one of the most frequent cancer types and is responsible for the highest mortality rate among women. Novel complementary strategies, including chemoprevention, have been suggested. As ${ }^{125} \mathrm{I}-\mathrm{BBI}$, when orally administrated in rodents, has been 
demonstrated in the bloodstream and distributed through the body [37-38], its chemopreventive properties could occur in breast tissue. In vitro studies have reported the potential of BBI as chemopreventive agents in breast cancer. Soybean BBI has been shown to inhibit, specifically and potently, the chymotrypsin-like proteasomal activity in MCF7 breast cancer cells in vitro and in vivo [78]. The proteasomal inhibition was associated with an accumulation of ubiquitinylated proteins and the proteasome substrates, p21 $1^{\mathrm{Cip} 1 / \mathrm{WAF} 1}$ and p27Kip1; a down-regulation of cyclin D1 and E was also observed. These authors suggested that soybean BBI abates proteasome function and, dependent on dose and time, up-regulates MAP kinase phosphatase-1 (MKP-1), which in turn suppresses phosphorylation coupled to extracellular signal-related kinase activity in MCF7 treated cells. The ability of soybean BBI to inhibit the proteasomal chymotrypsin-like activity in intact MCF7 cells suggests that the protease inhibitor can penetrate cells and facilitate the inhibition of intracellular target proteases. Recent findings have demonstrated that BBI from black-eye pea (Vigna unguiculata) induced apoptotic cell death in MCF7 breast cancer cells associated with severe cell morphological alterations, including the alteration of the nuclear morphology, plasma membrane fragmentation, cytoplasm disorganization, presence of double-membrane vesicles, mitochondrial swelling and lysosome membrane permeabilization [79].

\subsection{Radioprotection}

Radiotherapy is used in the treatment of a broad range of malignant tumors with the aim to inflict maximal damage on the tumor tissue. Exposure of surrounding normal tissue to therapeutic radiation should be minimized to avoid side effects that can have a significant impact on general status and quality of life of patients. The use of radioprotective agents to reduce the damage in normal tissue may improve the therapeutic benefit of radiotherapy. The radioprotective properties of BBI have been tested on cell cultures; so far, no data regarding efficacy in humans are available. Soybean BBI have shown potent and selective radioprotection of normal tissue in vitro [80] and in vivo [81], without protecting tumor tissue. Dittmann et al. [81] showed that soybean BBI increased clonogenic survival after irradiation only in cells, either normal or transformed, having a wild-type $p 53$ tumor suppressor gene. In a cell line with inducible expression of mutated $p 53$, the radioprotective effect of BBI was only detected when the expression of the mutated p53 was switched off [75]. The activation of the DNA-repair machinery, induced by pre-treatment of fibroblastic cells with soybean BBI, suggests a possible BBI-mediated p53-dependent mechanism for radioprotection $[82,83]$. Since a high number of tumors have lost $p 53$ function during their development, the clinical application of BBI to protect normal tissue from radiation damage would effectively improve the therapeutic outcome of radiotherapy.

The involvement of BBI in radiation-induced signaling cascades, and their role in stabilizing a specific tyrosine phosphatase that interferes with the activation of an epidermal growth factor receptor in response to radiation exposure, could be responsible for such protection [84]. Experiments carried out with linear forms of BBI demonstrated that the secondary structure of BBI, required for the protease inhibitory activity, was not necessary for its 
radioprotective properties [85]. The radioprotective effect of soybean BBI was mainly associated with the chymotrypsin inhibitory site [86] and could be mimicked using a synthetic linearized nonapeptide (CALSYPAQC), corresponding to the active site for chymotrypsin inhibition, but lacking protease inhibitor activity [85]. These observations provide opportunities for the use of synthetic peptides for protecting against ionizing radiation. BBI, when applied topically, once a day for 5 days, to SKH-1 hairless mice with a high risk of developing UV-induced skin tumors, inhibited the formation and growth of skin tumors [85]. In addition, topical application of nondenatured soymilk, once a day for a period of five days prior to UV irradiation, to mini-swine skin reduced or completely eliminated UVinduced formation of thymine dimers and apoptotic cells. Finally, BBIC appears to play a radioprotective role in radiation-induced cataract formation reducing the prevalence and severity of the lens opacifications in mice exposed to high-energy protons [88].

\section{Beneficial properties of Bowman-Birk inhibitors in non-related cancer diseases}

The loss of muscle protein due to inactivity, disease or aging is a process known as muscular atrophy or wasting. Skeletal muscular atrophy in response to disuse involves both a decrease in protein synthesis and increased protein degradation, predisposing humans to undergo a substantial loss of muscle mass. In connection with this, complex proteolytic cascades may provide a mechanism for the initiation of protein degradation during atrophy. Dietary intervention suggests possible therapeutic strategies via protease inhibition to diminish muscular atrophy and loss of strength following unloading. Skeletal muscular atrophy can be reproduced experimentally in rodents by hind-limb unloading. Dietary supplementation containing 1\% BBIC has been reported to inhibit unloading-induced weakness in mice [89], promoting redox homeostasis in muscle fibers and blunting atrophy-induced weakness [90]. Morris et al. [89] suggested that inhibiting muscle degrading proteases may provide a new pharmacological strategy in treating skeletal muscular atrophy; however, such proteases remain uncharacterized. More recently, oral administration of BBIC was reported to improve muscle mass and function and to modulate pathological processes in the mouse model of Duchenne muscular dystrophy ( $\mathrm{mdx}$ mouse) [91]. Chymase, a serine protease that is released from mast cells, is involved in inflammatory processes and is susceptible to inhibition by BBI, and hence has been suggested as a BBI target in mdx mice. Additional studies are necessary to elucidate the potential therapeutic role of BBI in muscular dystrophy.

Multiple sclerosis (MS) is a chronic inflammatory disease of the central nervous system characterized by progressive demyelination of the brain and spinal cord. Available therapeutic treatments have only limited efficacy and show significant side effects. The search for novel therapeutic agents that can be administered orally, and act synergistically with existing therapies, would be useful for patients with MS. Purified soybean BBI and BBIC have been shown to be effective in the suppression of experimental autoimmune encephalomyelitis in rodents, a model to study the pathogenic mechanisms of MS and to test potential therapies [92]. The oral administration of BBI in mice caused an improvement 
of several disease parameters (onset, severity, weight loss, inflammation, neuronal loss and demyelination), with no apparent adverse effects [93, 94]. Interestingly, BBI ameliorated disease, even when treatment was initiated after disease onset, via an IL-10-dependent mechanism [94]; the molecular basis for the induction of IL-10 production by BBI remains to be elucidated. Recent studies have demonstrated that BBI is responsible for delayed onset of disease but did not stop disease development, which became similarly severe in treated mice as in control animals $[95,96]$. The ability of soybean BBI to delay both inflammatory and neurodegenerative aspects of autoimmune encephalomyelitis suggests that it may be useful for treating acute MS exacerbations and neurological dysfunction.

\section{Concluding remarks}

In recent years, much effort has focused on clarifying the potential chemopreventive properties of BBI. Preclinical and clinical studies have clearly demonstrated that BBI uptake is well-tolerated and no side-effects were elicited. This is particularly relevant and lack of toxicity is a major consideration, given the necessity for prolonged duration of administration. Consistently, several studies have shown that serine proteases are potential BBI targets in prevention and therapy; however, these targets have not been proven thus far. The validation of specific serine proteases as BBI targets will contribute to the assessment of $\mathrm{BBI}$ as chemopreventive agents that may be used in preventive and/or therapeutic medicine.

\section{Author details}

Alfonso Clemente*, María del Carmen Marín-Manzano and María del Carmen Arques Department of Physiology and Biochemistry of Nutrition, Estación Experimental del Zaidin, Spanish Council for Scientific Research (CSIC), Granada, Spain

Claire Domoney

Department of Metabolic Biology, John Innes Centre, Norwich Research Park, Norwich, UK

\section{Acknowledgement}

A.C. acknowledges support by ERDF-co-financed grants from the Spanish CICYT (AGL2010-15877AGL and AGL2011-26353). A.C. is involved in COST Action FA1005 INFOGEST on Food Digestion. C.D. acknowledges support from the European Union (Grain Legumes Integrated Project, a Framework Programme 6 project, grant no. FOOD-CT2004-506223) and from Defra, United Kingdom (grant nos. AR0105 and AR0711).

\section{References}

[1] Turk B. Targeting Proteases: Successes, Failures and Future Prospects. Nature Reviews Drug Discovery 2006; 5: 785-799.

\footnotetext{
${ }^{*}$ Corresponding Autor
} 
[2] Shen A. Allosteric Regulation of Protease Activity by Small Molecules. Molecular Biosystems 2010; 6: 1431-1443.

[3] Drag M, Salvesen GS. Emerging Principles in Protease-based Drug Discovery. Nature Reviews Drug Discovery 2010; 9: 690-701.

[4] Deu E, Verdoes M, Bogyo M. New Approaches for Dissecting Protease Functions to Improve Probe Development and Drug Discovery. Nature Structural \& Molecular Biology 2012; 19: 9-16.

[5] Malkowicz SB, McKenna WG, Vaughn DJ, Wan XS, Propert KJ, Rockwell K, Marks SHF, Wein AJ, Kennedy AR. Effects of Bowman-Birk Inhibitor Concentrate (BBIC) in Patients with Benign Prostatic Hyperplasia. Prostate 2001; 48: 16-28.

[6] Armstrong WB, Kennedy AR, Wan XS, Atiba J, McLaren CE, Meyskens FL. Single-dose Administration of Bowman-Birk Inhibitor Concentrate in Patients with Oral Leukoplakia. Cancer Epidemiology, Biomarkers \& Prevention 2000; 9: 43-47.

[7] Armstrong WB, Kennedy AR, Wan XS, Taylor TH, Nguyen QA, Jensen J, Thompson W. Clinical Modulation of Oral Leukoplakia and Protease Activity by Bowman-Birk Inhibitor Concentrate in a Phase IIa Chemoprevention Trial. Clinical Cancer Research 2000; 6: 4684-4691.

[8] Meyskens FL, Taylor T, Armstrong W, Kong L, Gu M, Gonzalez R, Villa M, Wong V, Garcia A, Perloff M, Kennedy A, Wan S, Ware JH, Messadi D, Lorch J, Wirth L, Jaffe Z, Goodwin J, Civantos F, Sullivan M, Reid M, Merciznu M, Jayaprakash V, Kerr AR, Le A. Phase IIb Randomized Clinical Chemoprevention Trial of a Soybean-derived Compound (Bowman-Birk Inhibitor Concentrate) for Oral Leukoplakia. Cancer Prevention Research 2010; 3: CN02-05.

[9] Lichtenstein GR, Deren J, Katz S, Lewis JD, Kennedy AR, Ware JH. Bowman-Birk Inhibitor Concentrate: A Novel Therapeutic Agent for Patients with Active Ulcerative Colitis. Digestive Diseases and Sciences 2008; 53: 175-180.

[10] Bateman KS, James MNG. Plant Proteinase Inhibitors: Structure and Mechanism of Inhibition. Current Protein \& Peptide Science 2011; 12: 341-347.

[11] Domoney C, Welham T, Ellis N, Mozzanega P, Turner L. Three Classes of Proteinase Inhibitor Gene Have Distinct but Overlapping Patterns of Expression in Pisum sativum Plants. Plant Molecular Biology 2002; 48: 319-329.

[12] De Almeida B, Garcia da Silva W, Alves M, Gonzalves E. In silico Characterization and Expression Analysis of the Multigene Family Encoding the Bowman-Birk Protease Inhibitor in Soybean. Molecular Biology Reports 2012; 39: 327-334.

[13] Clemente A, Domoney C. Biological Significance of Polymorphism in Legume Protease Inhibitors from the Bowman-Birk Family. Current Protein \& Peptide Science 2006; 7: 201-216.

[14] Domoney C, Welham T. Trypsin Inhibitors in Pisum: Variation in Amount and Pattern of Accumulation in Developing Seed. Seed Science Research 1992; 2: 147-154.

[15] Clemente A, Gee JM, Johnson IT, Domoney C. Pea (Pisum sativum L.) Protease Inhibitors from the Bowman-Birk Class Influence the Growth of Human Colorectal Adenocarcinoma HT29 Cells in vitro. Journal of Agricultural and Food Chemistry 2005; 53: 8979-8986. 
[16] Page D, Aubert G, Duc G, Welham T, Domoney C. Combinatorial Variation in Coding and Promoter Sequences of Genes at the Tri Locus in Pisum sativum Accounts for Variation in Trypsin Inhibitor Activity in Seeds. Molecular Genetics and Genomics 2002; 267: 359-369.

[17] Wiseman J, Al-Mazooqi W, Welham T, Domoney C. The Apparent Ileal Digestibility, Determined with Young Broilers, of Amino Acids in Near-isogenic Lines of Peas (Pisum sativum L.) Differing in Trypsin Inhibitor Activity. Journal of the Science of Food and Agriculture 2003; 83: 644-651.

[18] Wiseman J, Al-Marzooqi W, Hedley C, Wang TL, Welham T, Domoney C. The Effects of Genetic Variation at $r, r b$ and Tri Loci in Pisum sativum L. on Apparent Ileal Digestibility of Amino Acids in Young Broilers. Journal of the Science of Food and Agriculture 2006; 86: 436-444.

[19] Hernández-Ledesma B, Hsieh CC, de Lumen BO. Lunasin and Bowman-Birk Protease Inhibitor (BBI) in US Commercial Soy Foods. Food Chemistry 2009; 115: 574-580.

[20] Bode W, Huber R. Natural Protein Proteinase-Inhibitors and their Interaction with Proteinases. European Journal of Biochemistry 1992; 204: 433-451.

[21] Chen P, Rose J, Love R, Wei CH, Wang BC. Reactive Sites of an Anticarcinogenic Bowman-Birk Proteinase Inhibitor are Similar to Other Trypsin Inhibitors. The Journal of Biological Chemistry 1992; 267: 1990-1994.

[22] Clemente A, Sonnante G, Domoney C. Bowman-Birk Inhibitors from Legumes on Human Gastrointestinal Health: Current Status and Perspectives. Current Protein \& Peptide Science 2011; 12: 358-373.

[23] Schechter I, Berger A. On the Size of the Active Site in Proteases. I. Papain. Biochemical and Biophysical Research Communications 1967; 27: 157-162.

[24] Rocco M, Marloni L, Chambery A, Poerio E, Parente A, Di Maro A. A Bowman-Birk Inhibitor with Anti-elastase Activity from Lathyrus sativus L. Seeds. Molecular Biosystems 2011; 7: 2500-2507.

[25] Piergiovanni AR, Galasso I. Polymorphism of Trypsin and Chymotrypsin Binding Loops in Bowman-Birk Inhibitors from Common Bean (Phaseolus vulgaris L.). Plant Science 2004; 166: 1525-1531.

[26] Clemente A, Moreno J, Marín-Manzano MC, Jiménez E, Domoney C. The Cytotoxic Effect of Bowman-Birk Isoinhibitors, IBB1 and IBBD2, from Soybean (Glycine max) on HT29 Human Colorectal Cancer Cells is Related to their Intrinsic Ability to Inhibit Serine Proteases. Molecular Nutrition \& Food Research 2010; 54: 396-405.

[27] Ferrasson E, Quillien L, Gueguen J. Proteinase Inhibitors from Pea Seeds: Purification and Characterization. Journal of Agricultural and Food Chemistry 1997; 45: 127-131.

[28] Clemente A, MacKenzie DA, Jeenes DJ, Domoney C. The Effect of Variation within Inhibitory Domains on the Activity of Pea Protease Inhibitors from the Bowman-Birk Class. Protein Expression and Purification 2004; 36: 106-114.

[29] Ragg EM, Galbusera V, Scarafoni A, Negri A, Tedeschi G, Consoni A, Sessa F, Duranti M. Inhibitory Properties and Solution Structure of a Potent Bowman-Birk Protease Inhibitor from Lentil (Lens culinaris, L.) Seeds. FEBS Journal 2006; 273: 4024-4039. 
[30] Caccialupi P, Ceci LR, Siciliano RA, Pignone D, Clemente A, Sonnante G. Bowman-Birk Inhibitors in Lentil: Heterologous Expression, Functional Characterisation and Antiproliferative Properties in Human Colon Cancer Cells. Food Chemistry 2010; 120: 10581066.

[31] Scarafoni A, Consonni A, Galbusera V, Negri A, Tedeshi G, Rasmussen P, Magni C, Duranti M. Identification and Characterization of a Bowman-Birk Inhibitor Active Towards Trypsin but not Chymotrypsin in Lupinus albus Seeds. Phytochemistry 2008; 69: 1820-1825.

[32] Osman MA, Reid PM, Weber CW. Thermal Inactivation of Tepary Bean (Phaseolus acutifolius), Soybean and Lima Bean Protease Inhibitors: Effect of Acidic and Basic $\mathrm{pH}$. Food Chemistry 2002; 78: 419-423.

[33] Clemente A, Vioque J, Sánchez-Vioque R, Pedroche J, Bautista J, Millán F. Factors Affecting the in vitro Protein Digestibility of Chickpea Albumins. Journal of the Science of Food and Agriculture 2000; 80: 79-84.

[34] Weder JK. Inhibition of Human Proteinases by Grain Legumes. Advances in Experimental Medicine and Biology 1986; 199: 239-279.

[35] Park JH, Jeong HJ, Lumen BOD. In Vitro Digestibility of the Cancer-Preventive Soy Peptides Lunasin and BBI. Journal of Agricultural and Food Chemistry 2007; 55: 1070310706.

[36] Trivedi MV, Laurence JS, Siahann TJ. The Role of Thiols and Disulfides on Protein Stability. Current Protein \& Peptide Science 2009; 10: 614-625.

[37] Billings PC, St Clair WH, Maki PA, Kennedy AR. Distribution of the Bowman-Birk Protease Inhibitor in Mice Following Oral Administration. Cancer Letters 1992; 62: 191197.

[38] Kennedy AR. Chemopreventive Agents: Protease Inhibitors. Pharmacology \& Therapeutics 1998; 78: 167-209.

[39] Hajós G, Gelencser E, Pustzai A, Grant G, Sakhri M, Bardocz S. Biological Effects and Survival of Trypsin Inhibitors and the Aglutinin from Soybean in the Small Intestine of the Rat. Journal of Agricultural and Food Chemistry 1995; 43: 165-170.

[40] Clemente A, Jiménez E, Marín-Manzano MC, Rubio LA. Active Bowman-Birk Inhibitors Survive Gastrointestinal Digestion at the Terminal Ileum of Pigs fed Chickpea-Based Diets. Journal of the Science of Food and Agriculture 2008; 88: 513-521.

[41] Marín-Manzano MC, Ruiz R, Jiménez E, Rubio LA, Clemente A. Anti-carcinogenic Soyabean Bowman-Birk Inhibitors Survive Fermentation in their Active Form and do not Affect the Microbiota Composition In Vitro. The British Journal of Nutrition 2009; 101: 967-971.

[42] Reddy BS. Novel Approaches in the Prevention of Colon Cancer by Nutritional Manipulation and Chemoprevention. Cancer Epidemiology, Biomarkers \& Prevention 2000; 9: 239-247.

[43] Pan MH, Lai CS, Wu JC, Ho CT. Molecular Mechanisms for Chemoprevention of Colorectal Cancer by Natural Dietary Compounds. Molecular Nutrition \& Food Research 2011; 55: 32-45. 
[44] Jemal A, Siegel R, Ward E, Hao YP, Xu JQ, Thun MJ. Cancer Statistics, 2009. Cancer Journal for Clinicians 2009; 59: 225-249.

[45] Kennedy AR, Billings OC, Wan XS, Newberne PM. Effects of Bowman-Birk Inhibitor on Rat Colon Carcinogenesis. Nutrition and Cancer 2002; 43: 174-186.

[46] Chan AT, Baba Y, Sima K, Nosho K, Chung DC, Hung KE, Mahmood U, Madden K, Poss K, Ranieri A, Shue D, Kucherlapati R, Fuch CS, Ogino S. Cathepsin B Expression and Survival in Colon Cancer: Implications for Molecular Detection of Neoplasia. Cancer Epidemiology, Biomarkers \& Prevention 2010; 19: 2777-2785.

[47] Weldon S, McNally P, McElvaney NG, Elborn JS, McAuley DF, Wartelle J, Belaaouaj A, Levine RJ, Taggart CC. Decrease Levels of Secretory Leukoprotease Inhibitor in the Pseudomonas-Infected Cystic Fibrosis Lung are Due to Neutrophil Elastase Degradation. Journal of Immunology 2009; 183: 8148-8156.

[48] Inoue Y, Yokobori T, Yokoe T, Toiyama Y, Miki C, Mimori K, Mori M, Kusunoki M. Clinical Significance of Human Kallikrein7 Gene Expression in Colorectal Cancer. The Annals of Surgical Oncology 2010; 17: 3037-3042.

[49] Petraki C, Dubinski W, Scorilas A, Saleh C, Pasic MD, Komborozo V, Khalil B, Gabril MY, Streutker C, Diamandis EP, Yousef GM. Evaluation and Prognostic Significance of Human Tissue Kallikrein-related Peptidase 6 (KLK6) in Colorectal Cancer. Pathology Research and Practice 2012; 208: 104-108.

[50] Scott CJ, Taggart CC. Biologic Protease Inhibitors as Novel Therapeutic Agents. Biochimie 2010; 92: 1681-1688.

[51] Wu WKK, Cho CH, Lee CW, Wu K, Fan D, Yu J, Sung JJY. Proteasome Inhibition: a New Therapeutic Strategy to Cancer Treatment. Cancer Letters 2010; 293: 15-22.

[52] Latonen L, Moore HM, Bai B, Jaamaa S, Laiho M. Proteasome Inhibitors Induce Nucleolar Aggregation of Proteasome Target Proteins and Polyadenylated RNA by Altering Ubiquitin Availability. Oncogene 2011; 30: 790-805.

[53] Bugge TH, Antalis TM, Wu Q. Type II Transmembrane Serine Proteases. Journal of Biological Chemistry 2009; 284: 23177-23181.

[54] Lee SL, Dickson RB, Lin CY. Activation of Hepatocyte Growth Factor and Urokinase/Plasminogen Activator by Matriptase, an Epithelial Membrane Serine Protease. Journal of Biological Chemistry 2000; 275: 36720-36725.

[55] Yamasaki Y, Satomi S, Murai N, Tsuzuki S, Fushiki T. Inhibition of Membrane-Type Serine Protease 1/Matriptase by Natural and Synthetic Protease Inhibitors. Journal of Nutritional Science and Vitaminology 2003; 49: 27-32.

[56] Billings PC, Newberne P, Kennedy AR. Protease Inhibitor Suppression of Colon and Anal Gland Carcinogenesis Induced by Dimethylhydrazine. Carcinogenesis 1990; 11: 1083-1086.

[57] Ware HW, Wan S, Newberne P, Kennedy AR. Bowman-Birk Concentrate Reduces Colon Inflammation in Mice with Dextran Sulphate Sodium-Induced Ulcerative Colitis. Digestive Diseases and Sciences 1999; 44: 986-990.

[58] de Paula A, de Abreu P, Santos KT, Guerra R, Martins C, Castro-Borges W, Guerra MH. Bowman-Birk Inhibitors, Proteasome Peptidase Activities and Colorectal Pre-neoplasias 
Induced by 1,2-dimethylhydrazine in Swiss Mice. Food and Chemical Toxicology 2012; 50: 1405-1412.

[59] Sutherland LR, Martin F, Greer S, Robinson M, Greenberger N, Saibil F, Martin T, Sparr J, Prokipchuck E, Borgen L. 5-aminosalicylic Acid Enema in the Treatment of Distal Ulcerative Colitis, Proctosigmoiditis and Proctitis. Gastroenterology 1987; 92: 1894-1898.

[60] Frenkel K, Chranzan K, Ryan CA, Wiesner R, Troll W. Chymotrypsin-specific Protease Inhibitors Decrease $\mathrm{H}_{2} \mathrm{O}_{2}$ Formation by Activated Human Polymorphonuclear Leukocytes. Carcinogenesis 1987; 8: 1207-1212.

[61] Baturay NZ, Roque H. In vitro Reduction of Peroxidation in UVC Irradiated Cell Cultures by Concurrent Exposure with Bowman-Birk Protease Inhibitor. Teratogenesis, Carcinogenesis and Mutagenesis 1991; 11: 195-202.

[62] Larionova NI, Gladysheva IP, Tikhonova TV, Kazanskaya NF. Inhibition of Cathepsin G and Human Granulocyte Elastase by Multiple Forms of Bowman-Birk Type Soybean Inhibitor. Biochemistry-Moscow 1993; 58: 1046-1052.

[63] Gladysheva IP, Zamolodchikova TS, Sokolova EA, Larionova NI. Interaction Between Duodenase, a Proteinase with Dual Specificity, and Soybean Inhibitors of Bowman-Birk and Kunitz Type. Biochemistry-Moscow 1999; 64: 1244-1249.

[64] Ware JH, Wan XS, Rubin H, Schechter NM, Kennedy AR. Soybean Bowman-Birk Protease Inhibitor is a Highly Effective Inhibitor of Human Mast Cell Chymase. Archives of Biochemistry and Biophysics 1997; 344: 133-138.

[65] Tani K, Ogushi K, Kido H, Kawano T, Kumori Y, Kamikura T, Cui P, Sone S. Chymase is a Potent Chemoattractant for Human Monocytes and Neutrophils. Journal of Leukocyte Biology 2000; 67: 585-589.

[66] Saarinen J, Kalkkinen N, Welgus HG, Kovanen PT. Activation of Human Interstitial Procollagenase through Direct Cleavage of the Leu83- Thr84 Bond by Mast Cell Chymase. Journal of Biological Chemistry 1994; 269: 18134-18140.

[67] Mizutani H, Schechter NM, Lazarus G, Black RA, Kupper TS. Rapid and Specific Conversion of Precursor Interleukin 1beta (1L-beta) to an Active IL-1 Species by Human Mast Cell Chymase. Journal of Experimental Medicine 1991; 174: 821-825.

[68] Clemente A, Marín-Manzano MC, Jiménez E, Arques MC, Domoney C. The Antiproliferative Effects of TI1B, a Major Bowman-Birk isoinhibitor from Pea (Pisum sativum L), on HT29 Colon Cancer Cells are Mediated Through Protease Inhibition. The British Journal of Nutrition 2012 (doi.10.1017/S000711451200075X).

[69] Wan XS, Meyskens FL, Armstrong WB, Taylor TH, Kennedy AR. Relationship Between Protease Activity and neu Oncogene Expression in Patients with Oral Leukoplakia Treated with the Bowman-Birk Inhibitor. Cancer Epidemiology, Biomarkers \& Prevention 1999; 8: 601-608.

[70] Shirai T. Significance of Chemoprevention for Prostate Cancer Development: Experimental in vivo Approaches to Chemoprevention. Pathology International 2008; 58: 1-6.

[71] Yan L, Spitznagel EL. Meta-analysis of Soy Food and Risk of Prostate Cancer in Men. International Journal of Cancer 2005; 117: 667-669. 
[72] Wan XS, Ware JH, Zhang L, Newberne PM, Evans SM, Clark CL, Kennedy AR. Treatment with Soybean-derived Bowman Birk Inhibitor Increases Serum Prostatespecific Antigen Concentration while Suppressing Growth of Human Prostate Cancer Xenografts in Nude Mice. Prostate 1999b; 41: 243-252.

[73] Kennedy AR, Wan XS. Effects of the Bowman-Birk Inhibitor on Growth, Invasion, and Clonogenic Survival of Human Prostate Epithelial Cells and Prostate Cancer Cells. Prostate 2002; 50: 125-133.

[74] Sun XY, Donald SP, Phang JM. Testosterone and Prostate Specific Antigen Stimulate Generation of Reactive Oxygen Species in Prostate Cancer Cells. Carcinogenesis 2001; 22: $1775-1780$.

[75] Dittmann K, Virsik-Kopp P, Mayer C, Rave-Frank M, Rodemann HP. The Radioprotective Effect of BBI Is Associated with the Activation of DNA Repair-Relevant Genes. International Journal of Radiation Oncology 2003; 79: 801-808.

[76] McCormick DL, Johnson WD, Bosland MC, Lubet RA, Steele VE. Chemoprevention of Rat Prostate Carcinogenesis by Soy Isoflavones and Bowman-Birk Inhibitor. Nutrition and Cancer 2007; 57: 184-193.

[77] Tang MX, Asamoto M, Ogawa K, Naiki-Ito A, Sato S, Takahashi S, Shirai T. Induction of Apoptosis in the LNCaP Human Prostate Carcinoma Cell Line and Prostate Adenocarcinomas of SV40T Antigen Transgenic Rats by the Bowman-Birk. Pathology International 2009; 59: 790-796.

[78] Chen YW, Huang SC, Lin-Shiau SY, Lin JK. Bowman-Birk Inhibitor Abates Proteasome Function and Suppresses the Proliferation of MCF7 Breast Cancer Cells Through Accumulation of MAP Kinase Phosphatase-1. Carcinogenesis 2005; 26: 1296-1305.

[79] Joanitti GA, Azevedo RB, Freitas SM. Apoptosis and Lysosome Membrane Permeabilization Induction on breast Cancer Cells by an Anticarcinogenic BowmanBirk Inhibitor from Vigna unguiculata Seeds. Cancer Letters 2010; 293: 73-81.

[80] Dittmann K, Löffler H, Bamberg M, Rodemann HP. Bowman-Birk Proteinase Inhibitor (BBI) Modulates Radiosensitivity and Radiation-Induced Differentiation of Human Fibroblasts in Culture. Radiotherapy and Oncology 1995; 34: 137-143.

[81] Dittmann K, Toulany M, Classen J, Heinrich V, Milas L. Selective Radioprotection of Normal Tissues by Bowman-Birk Proteinase Inhibitor (BBI) in Mice. Strahlentherapie Und Onkologie 2005; 181: 191-196.

[82] Dittmann KH, Gueven N, Mayer C, Ohneseit P, Zell P, Begg AC, Rodemann HP. The Presence of Wild-Type TP53 is Necessary for the Radioprotective Effect of the BowmanBirk Proteinase Inhibitor in Normal Fibroblasts. Radiation Research 1998; 150: 648-655.

[83] Dittmann K, Mayer C, Kehlbach R, Rodemann HP. The Radioprotector Bowman-Birk Proteinase Inhibitor Stimulates DNA Repair via Epidermal Growth Factor Receptor Phosphorylation and Nuclear Transport. Radiotherapy and Oncology 2008; 86: 375-382.

[84] Gueven N, Dittmann K, Mayer C, Rodemann HP. Bowman-Birk Protease Inhibitor Reduces the Radiation-Induced Activation of the EGF Receptor and Induces Tyrosine Phosphatase Activity. International Journal of Radiation Oncology 1998; 73: 157-162. 
[85] Gueven N, Dittmann K, Mayer C, Rodemann HP. The Radioprotective Potential of the Bowman-Birk Protease Inhibitor is Independent of its Secondary Structure. Cancer Letters 1998; 125: 77-82.

[86] Yavelow J, Collins M, Birk Y, Troll W, Kennedy AR. Nanomolar Concentrations of Bowman-Birk Soybean Protease Inhibitor Suppress X-ray Induced Transformation In Vitro. Proceedings of the National Academy of Sciences of the United States of America 1985; 82: 5395-5399.

[87] Huang MT, Xie JG, Lin CB, Kizoulis M, Seiberg M, Shapiro S, Conney A. Inhibitory Effect of Topical Applications of Non-denatured Soymilk on the Formation and Growth of UVB-Induced Skin Tumors. Oncology Research 2004; 14: 387-397.

[88] Davis JG, Wan XS, Ware JH, Kennedy AR Dietary Supplements Reduce the Cataractogenic Potential of Proton and HZE-Particle Radiation in Mice. Radiation Research 2010; 173: 353-361.

[89] Morris CA, Morris LD, Kennedy AR, Sweeney HL. Attenuation of Skeletal Muscle Atrophy via Protease Inhibition. Journal of Applied Physiology 2005; 99: 1719-1727.

[90] Arbogast S, Smith J, Matuszczak Y, Hardin BJ, Moylan JS, Smith JD, Ware J, Kennedy AR, Reid MB. Bowman-Birk Inhibitor Concentrate Prevents Atrophy, Weakness, and Oxidative Stress in Soleus Muscle of Hindlimb-Unloaded Mice. Journal of Applied Physiology 2007; 102: 956-964.

[91] Morris CA, Selsby JT, Morris LD, Pendrak K, Sweeney HL. Bowman-Birk Inhibitor Attenuates Dystrophic Pathology in mdx Mice. Journal of Applied Physiology 2010; 109: 1492-1499.

[92] Cruz-Orengo L, Holman DW, Dorsey D, Zhou L, Zhang P, Wright M, McCandless EE, Patel JR, Luker GD, Littmann DR, Rusell JH, Klein RS. CXCR7 Influences Leukocyte Entry into the CNS Parenchyma by Controlling Abluminal CXCL12 Abundance During Autoimmunity. Journal of Experimental Medicine 2011; 208: 327-339.

[93] Gran B, Tabibzadeh N, Martin A, Ventura ES, Ware JH, Zhang GX, Parr JL, Kennedy AR, Rostami AM. The Protease Inhibitor, Bowman-Birk inhibitor, Suppresses Experimental Autoimmune Encephalomyelitis: a Potential Oral Therapy for Multiple Sclerosis. Multiple Sclerosis 2006; 12: 688-697.

[94] Touil T, Ciric B, Ventura E, Shindler KS, Gran B, Tostami A. Bowman-Birk Inhibitor Suppresses Inflammation and Neuronal Loss in a Mouse Model of Multiple Sclerosis. Journal of the Neurological Sciences 2008; 271: 191-202.

[95] Dai H, Ciric B, Zhang GX, Rostami A. Bowman-Birk Inhibitor Attenuates Experimental Autoimmune Encephalomyelitis by Delaying Infiltration of Inflammatory Cells into the CNS. Immunologic Research 2011; 51: 145-152.

[96] Dai H, Ciric B, Zhang GX, Rostami A. Interleukin-10 Plays a Crucial Role in Suppression of Experimental Autoimmune Encephalomyelitis by Bowman-Birk Inhibitor. Journal of Neuroimmunology 2012; 245: 1-7.

[97] Scarpi D, McBride JD, Leatherbarrow RJ. Inhibition of Human Beta-Tryptase by Bowman-Birk Inhibitor Derived Peptides: Creation of a New Tri-Functional Inhibitor. Bioorganic \& Medicinal Chemistry 2004; 12: 6045-6052. 
[98] Muricken DG, Gowda LR Molecular Engineering of a Small Trypsin Inhibitor Based on the Binding Loop of Horsegram Seed Bowman-Birk Inhibitor. Journal of Enzyme Inhibition and Medicinal Chemistry 2011; 26: 553-560.

[99] Rocco M, Malorni L, Chambery A, Poerio E, Parente A, Di Maro A. A Bowman-Birk Inhibitor with Anti-Elastase Activity from Lathyrus sativus L. Seeds. Molecular Biosystems 2011; 7: 2500-2507.

[100] Fernandes AO, Banerji AP. Inhibition of Benzopyrene-Induced Forestomach Tumors by Field Bean Protease Inhibitor. Carcinogenesis 1995; 16: 1843-1846. 